Food and Agriculture Organization of the United Nations: Committee on Calorie Requirements (1950). F.A.O. nutr. Stud. no. 5 .

Gray, E. le B., Consolazio, F. C. \& Kark, R. M. (195I). F. appl. Physiol. 4, 270.

Hindmarsh, E. M. (1927). Aust. F. exp. Biol. med. Sci. 4, 225.

Houghten, F. C. \& Yagloglou, C. P. (1923). F. Amer. Soc. Heat. Vent. Engrs, 30, I69.

Johnson, R. E. (1943). Gastroenterology, 1, 832.

Johnson, R. E. \& Kark, R. M. (1947). Science, Io5, 378

Kark, R. M., Aiton, H. F., Pease, E. D., Bean, W. B., Henderson, C. R., Johnson, R. E. \& Richardson, L. M. (1947). Medicine, 26, I.

Lee, D. H. K. (1940). Pap. Dep. Physiol. Univ. Qd, r, no. 5 .

Lusk, G. (1928). The Elements of the Science of Nutrition, $4^{\text {th }}$ ed. Philadelphia \& London: W. B. Saunders Co.

Macpherson, R. K. (1949). Pap. Dep. Physiol. Univ. Qd, I, no. ro.

McArdle, B., Dunham, W., Holling, H. E., Ladell, W. S. S., Scott, J. W., Thompson, M. L. \& Weiner, J. S. (1947). Report Prepared for the Habitability Sub-committee of the Royal Naval Personnel Research Committee, R.N.P. 47/39I.

Mitchell, H. H. \& Edman, M. (1951). Nutrition and Climatic Stress with Particular Reference to Man. Springfield, 11l.: Charles C. Thomas.

Mitchell, H. H., Hamilton, T. S. \& Haines, W. T. (1949). F. biol. Chem. 178, 345.

Pitts, G. C., Johnson, R. E. \& Consolazio, F. C. (1944). Amer. F. Physiol. 142, 253.

Platt, B. S. (1945). Spec. Rep. Ser. med. Res. Coun., Lond., no. 253.

Platt, B. S. (1946). Proc. Nutr. Soc. 5, 2.

Quenouille, M. H., Boyne, A. W., Fisher, W. B. \& Leitch, I. (I95I). Tech. Commun. Bur. Anim. Nutr., Aberd, no. r7.

Talbott, H. H., Edwards, H. T., Dill, D. B. \& Drastich, L. (1933). Amer. F. trop. Med. 13, 381 .

Widdowson, E. M. \& McCance, R. A. (1943). Lancet, 244, 230.

\title{
Himalayan Rations with Special Reference to the 1953 Expedition to Mount Everest
}

\author{
By L. G. C. Pugh, Division of Human Physiology, Medical Research Council
}

Laboratories, Hampstead, London, N.W.3

Himalayan rations usually consist of a combination of bulk stores taken out from England or obtained in India and of foodstuffs purchased locally in the Himalayas. Rice, potatoes, tsampa (coarse flour made from roasted barley), dhal (a kind of lentil), eggs, chickens and meat are the chief foods available locally; fresh fruit and vegetables are seldom, if ever, obtainable.

The earlier Everest expeditions took with them a great variety of bulk stores. Later expeditions have come to depend increasingly on local food supplies, limiting their bulk stores to essential items not procurable locally, such as tea, powdered milk, sugar, jam, biscuits and butter.

\section{Experience gained on expedition to Cho Oyu, $195^{2}$}

On the expedition to Cho Oyu in 1952, which may be taken as typical of British postwar expeditions, a survey was made of nutritional and dietary problems. Measurements of the oxygen consumption of members of the party climbing at their normal pace at various altitudes made it possible to construct an approximate 
energy balance sheet for the period of the approach and for the time spent at high altitude (Table I). The demand for calories during the approach march was fairly well met, but the bulky and strange diet gave rise to rather severe disturbances

Table I. Analysis of diets, and intake and output of energy during the British expedition to Cho Oyu in 1952

\begin{tabular}{|c|c|c|c|c|c|c|}
\hline \multirow[b]{2}{*}{ Date } & \multirow[b]{2}{*}{$\begin{array}{l}\text { Activity and } \\
\text { altitude (ft.) }\end{array}$} & \multicolumn{4}{|c|}{ Intake of } & \multirow{2}{*}{$\begin{array}{l}\text { Expenditure } \\
\text { of energy } \\
\text { (Cal.) }\end{array}$} \\
\hline & & $\begin{array}{l}\text { Protein } \\
\text { (g) }\end{array}$ & $\begin{array}{l}\text { Fat } \\
\text { (g) }\end{array}$ & $\begin{array}{c}\text { Carbohydrate } \\
\text { (g) }\end{array}$ & $\begin{array}{l}\text { Calories } \\
\text { (Cal.) }\end{array}$ & \\
\hline $\begin{array}{l}\text { 30 March to } \\
17 \text { April }\end{array}$ & $\begin{array}{l}\text { Approach march } \\
\text { I000-I I, } 500\end{array}$ & 108 & IIO & 713 & 4267 & 4370 \\
\hline $\begin{array}{l}\text { I May to } \\
\text { Io May }\end{array}$ & $\begin{array}{l}\text { Attempts to climb } \\
\text { Cho Oyu } \\
\text { I9,000-22,500 }\end{array}$ & 42 & $7 I$ & 596 & 3189 & 3960 \\
\hline $\begin{array}{l}\text { I5 May to } \\
\text { I9 May }\end{array}$ & $\begin{array}{l}\text { Rest period at } \\
\text { Chule } \\
\text { I } 5,500\end{array}$ & 64 & 90 & 640 & 3626 & 3220 \\
\hline
\end{tabular}

of the digestive system in some individuals. Menus are shown in Table 2. During the period at high altitude, there was marked reduction in appetite, and a large proportion of the daily food intake was consumed in the form of sugar in beverages. Some members of the party developed cravings for specific items of food such as pineapple cubes and tinned salmon which were not available.

Table 2. Menus of the British expedition to Cho Oyu in $195^{2}$

\begin{tabular}{|c|c|c|c|c|c|c|}
\hline \multirow[b]{2}{*}{$\begin{array}{l}\text { Activity and } \\
\text { altitude (ft.) }\end{array}$} & \multicolumn{6}{|c|}{ Foods provided } \\
\hline & $\begin{array}{l}\text { Early } \\
\text { morning }\end{array}$ & Breakfast & $\begin{array}{l}\text { During } \\
\text { march or } \\
\text { climb }\end{array}$ & Lunch & Tea & Supper \\
\hline $\begin{array}{l}\text { Approach } \\
\text { march } \\
1000-\text { I I,500 }\end{array}$ & $\begin{array}{l}\text { Tsampa, } \\
\text { milk, sugar, } \\
\text { tea with milk } \\
\text { and sugar }\end{array}$ & $\begin{array}{l}\text { Grapenuts, } \\
\text { milk, sugar, } \\
\text { bacon and eggs, } \\
\text { butter, jam, } \\
\text { chupatties*, } \\
\text { tea with milk } \\
\text { and sugar }\end{array}$ & $\begin{array}{l}\text { Biscuits, } \\
\text { chocolate, } \\
\text { sweets }\end{array}$ & $\begin{array}{l}\text { Chupatties*, } \\
\text { butter, } \\
\text { jam, } \\
\text { tea with } \\
\text { milk and } \\
\text { sugar }\end{array}$ & $\begin{array}{l}\text { Tea } \\
\text { with } \\
\text { milk } \\
\text { and } \\
\text { sugar }\end{array}$ & $\begin{array}{l}\text { Soup, } \\
\text { curry, } \\
\text { rice, } \\
\text { potatoes, } \\
\text { dhal, } \\
\text { coffee with } \\
\text { milk and sugar }\end{array}$ \\
\hline $\begin{array}{l}\text { Cho Oyu } \\
19,000-22,500\end{array}$ & - & $\begin{array}{l}\text { Butter, jam, } \\
\text { biscuits, } \\
\text { grapenuts, } \\
\text { milk, sugar, } \\
\text { tea with } \\
\text { milk and sugar }\end{array}$ & $\begin{array}{l}\text { Sweets, } \\
\text { dates, } \\
\text { raisins }\end{array}$ & $\begin{array}{l}\text { Biscuits, } \\
\text { butter, } \\
\text { jam, } \\
\text { tea with } \\
\text { milk and } \\
\text { sugar }\end{array}$ & $\begin{array}{l}\text { Tea } \\
\text { with } \\
\text { milk } \\
\text { and } \\
\text { sugar }\end{array}$ & $\begin{array}{l}\text { Pemmican soup } \\
\text { bacon, } \\
\text { potatoes, } \\
\text { cocoa with } \\
\text { milk and } \\
\text { sugar }\end{array}$ \\
\hline $\begin{array}{l}\text { Chule } \\
15,500\end{array}$ & - & $\begin{array}{l}\text { Grapenuts, } \\
\text { milk, sugar, } \\
\text { bacon, } \\
\text { fried potatoes, } \\
\text { tea with } \\
\text { milk and sugar }\end{array}$ & $\begin{array}{l}\text { Biscuits, } \\
\text { tea with } \\
\text { milk and } \\
\text { sugar }\end{array}$ & $\begin{array}{l}\text { Chupatties*, } \\
\text { biscuits, } \\
\text { butter, jam, } \\
\text { tea with } \\
\text { milk and } \\
\text { sugar }\end{array}$ & $\begin{array}{l}\text { Tea } \\
\text { with } \\
\text { milk } \\
\text { and } \\
\text { sugar }\end{array}$ & $\begin{array}{l}\text { Pemmican, } \\
\text { potatoes, } \\
\text { cocoa with } \\
\text { milk and } \\
\text { sugar }\end{array}$ \\
\hline
\end{tabular}


Nor do they eliminate wastage. As much as $20 \%$ of a bag of cubes may be rendered unusable from powdering in the bag itself; a half-eaten cube may be drawn through the bars of the basket into the cage and abandoned, while the animal gets to work on a new one. The fragments get mixed up with the bedding or fall through the wire bottom of the cage, out of reach. All these may be faults in fabrication of the cube or of the baskets, but they are common faults, pointing to an inherent weakness in the system. Lastly, there is the question of palatability or acceptability. Why are the fragments pulled through the wires, abandoned and not eaten? Why do young guinea-pigs (especially) pick up pellets from the hopper and promptly drop them in the cages to seek, in vain, for something more to their taste?

All rodents will readily consume whole grains, and cereals must form a high proportion of their diet. The extra protein, from fish meal, skim milk and the like, can as easily be compounded in granules of similar size as in any other form, and be given alongside, in the same hopper. There is no difficulty about providing a suitable hopper for such a mixed diet; indeed, such hoppers have been in use in some laboratories for years.

This new approach to food presentation has many advantages, namely: (I) the quality of ingredients can be easily supervised in the laboratory; (2) the formula can be varied at will under laboratory conditions, so that (3) pilot experiments on different diets can be easily conducted, in which (4) the animal's ability to pick and choose to some extent can be observed and may assist in the devising of a really satisfactory formula; (5) the composition of the whole diet is more likely to approximate the sum of the compositions of its ingredients, for there will be less chance of interaction between ingredients; (6) acceptability or palatability is likely to be no less than in cubes, it might be greater.

\section{Summary}

The modern habit of feeding cubed or pelleted compound diets, with or without supplements, is convenient but has certain disadvantages, which may be inherent in the system. The impression of standardization in named diets is unreliable, nor can it be assumed that the composition of a compound diet is equal to the sum of the compositions of its ingredients.

Further advance in the feeding of laboratory animals should pay more attention to the biological needs of the animal; this may mean including at least a proportion of unprocessed food, such as cereal grains, in the diet.

\section{REFERENCES}

Bruce, H. M. (1950). F. Hyg., Camb., 48, I71.

Lane-Petter, W. \& Dyer, F. J. (1952). Lab. Anim. Bur. Tech. Note no. 7.

Parkes, A. S. (1945-6). F. Hyg., Camb., 44, 49 I.

Plouvier, L. (I953). L'Alimentation des Animaux de Laboratoire. Memoire Sorolabo, Paris. 
Table 3. Rations for Everest expedition, $1953:(A)$ composite ration for general use and $(B)$ modified assault ration for 2 man-days

(A)

Compo box providing I 4 man-days. Menu no. 7 , Sunday

\begin{tabular}{|c|c|c|}
\hline Item & $\begin{array}{c}\text { No. of } \\
\text { tins }\end{array}$ & $\begin{array}{l}\text { tin contents } \\
(o z .)\end{array}$ \\
\hline \multicolumn{3}{|l|}{ Bottom layer. Breakfast } \\
\hline Oatmeal biscuits & I & 12 \\
\hline Bacon & 5 & 12 \\
\hline Butter & 2 & 15 \\
\hline Jam & 2 & 9 \\
\hline Marmalade & 2 & 9 \\
\hline Cheese & 2 & 8 \\
\hline Chocolate and sweets & 3 & $\begin{array}{c}12 \frac{1}{2} \\
\text { (10 oz. chocolate, } \\
2 \frac{1}{2} \text { oz. sweets) }\end{array}$ \\
\hline Salt & I & 4 \\
\hline Matches & One box & \\
\hline \multicolumn{3}{|l|}{ Top layer. Main meal } \\
\hline Stewed steak & 8 & 16 \\
\hline Peas & 3 & 10 \\
\hline Cake & 4 & ro \\
\hline \multicolumn{3}{|l|}{ On top of tins } \\
\hline Soup powder & 2 & $2 \frac{1}{2}$ \\
\hline Fibre cloths & Two & \\
\hline Latrine paper & One packet & \\
\hline Tin opener & One & \\
\hline
\end{tabular}

Biscuit box, providing $6 \mathrm{oz} / \mathrm{man} / \mathrm{day}$, containing six tins each holding fifteen $6 \mathrm{oz}$. packets of biscuits

Beverage box for 28 man-days containing two trays, contents of each tray consisting of :

Sugar $\quad$ Item
Tea
Milk powder
One minute Quaker Oats
Stoned dates
Seedless raisins
Coffee or cocoa

$\begin{array}{cc}\text { No. of } & \begin{array}{c}\text { Weight of } \\ \text { packet } \\ \text { packets }\end{array} \\ 4 & \text { (oz.) } \\ 2 & 19 \frac{1}{2} \\ 4 & 10 \\ \text { I } & 8 \\ 2 & 16 \\ \text { I } & 8 \\ 2 & 16 \\ & 13\end{array}$

(B)

Rolled oats
Milk powder
Sugar
Jam
Sweet biscuits
Mint bar or banana bar
Cheese
Cocoa
Tea
Soup powder
Lemonade powder
Salt

$\begin{array}{cc}\text { No. of } & \begin{array}{c}\text { Weight of } \\ \text { packet } \\ \text { packets }\end{array} \\ 2 & \text { (oz.) } \\ 2 & 3 \\ 4 & 7 \\ 1 & 2 \\ 2 & 3 \\ 2 & 2 \\ 2 & \text { I } \\ 1 & \text { I } \\ & \text { I } \frac{1}{2} \\ 2 & 2 \frac{1}{4} \\ 2 & 5 \frac{1}{2} \text { g dispenser }\end{array}$

To be supplemented with luxury items individually selected. 
General purpose composite ration

The general purpose composite ration was packed as follows:

The compo boxes were weatherproof fibre-board cases of gross weight $45 \mathrm{lb}$,, containing an evening meal, breakfast, and food for the day's climbing for fourteen men for I day. All the items were packed in tins. There were five varieties of meat, as well as salmon, four varieties of vegetables, tinned fruit, cake, oatmeal biscuits, butter, jam, marmalade, chocolate and other items. By combining the meat, vegetables, fruit and cake in different ways, different menus were provided for each day of the week, and the boxes were labelled accordingly. The precise quantities of each item depended to some extent on the size of the tins available in army stocks. A specimen menu for I day is given in Table 3 .

The biscuit boxes were crates of gross weight $33^{\frac{3}{4}} \mathrm{lb}$. containing six hermetically sealed tin boxes, each holding fifteen $6 \mathrm{oz}$. packets of service biscuits. The biscuit ration was $6 \mathrm{oz} . / \mathrm{man} / \mathrm{day}$, but $4 \frac{1}{2} \mathrm{oz}$. would have been enough.

The beverage boxes were fibre-board cases of gross weight $35 \mathrm{lb}$., containing 2 days' rations of sugar, porridge oatmeal, tea and coffee or cocoa for fourteen men, as well as other items not requiring variation and suitable for vacuum packing. There were no tins in the beverage boxes (Table 3 ).

It was intended to supplement the above rations with potatoes, rice, dhal and occasionally fresh meat purchased locally. The calorie value of the composite ration, apart from locally purchased items, was approximately $4800 \mathrm{Cal} / \mathrm{man}$ daily. The intake based on the Cho Oyu study was not expected to be more than 4500 Cal. The surplus food was intended for the high-altitude Sherpas, who joined the expedition from Darjeeling, to supplement their diet of atta (stone-ground whole wheat flour), rice, tsampa and potatoes. Since the Sherpas were responsible for the cooking, a certain amount of leakage to them was in any event to be expected.

\section{'Assault' ration}

For use at high altitude where the 'compo' rations would no longer be acceptable on the score of weight, and where the sugar requirements would be very large, a special $24 \mathrm{~h}$ 'assault' ration was provided. This consisted of basic foods only, all of which were vacuum packed.

It was arranged to supplement the assault ration with so-called luxuries chosen by climbers according to their individual tastes and taken out from England in bulk. The calorie value of the assault ration was higher than would be required, and it was planned that individuals should modify their rations on the spot and reject items they felt they would be unable to eat. Actually, seventy assault rations were modified according to an agreed plan at base camp ( $8,000 \mathrm{ft}$.). Each modified unit consisted of two men's rations for I day packed in a single pouch (Table 3 ). The original assault ration contained, in addition to the items given in Table $3,2 \frac{1}{2} \mathrm{oz}$. low-fat pemmican and $3 \mathrm{oz}$. grapenuts, both of which were considered acceptable on Cho Oyu but were rejected in the modified ration.

The views and opinions of the climbers with regard to the feeding of the I 953 
expedition were collected by means of a questionnaire after the return of the expedition. All except one of the party agreed with the principle of taking composite rations as opposed to bulk rations. Most of the men wanted more local food, especially more fresh and less tinned meat. Adequate supplies of fresh meat, however, are not always procurable in the Himalayas, as was found on the return march, by which time the compo rations were finished.

It was agreed that packed rations for the assault should include only basic items acceptable to all (a difficult requirement !), and should be supplemented by individually selected items as was done on the present expedition.

Compo rations were still in demand at a greater altitude than had been anticipated, in fact up to Camp 4 at 21,200 ft., for which the probable explanation was partly that the party was better acclimatized than in $195^{2}$ and partly that the variety and palatability of the food were greater. The provision of enough pressure cookers and well-designed Primus stoves greatly assisted the preparation of meals and ensured an adequate supply of fluid for drinking.

At the higher camps, the modified assault rations proved satisfactory and were supplemented by such items as sardines, salmon, honey, Vitawheat, saucisson, and tinned fruit, part of which was derived from Swiss supplies left behind on the South $\mathrm{Col}(26,000 \mathrm{ft}$.) the previous year. Climbers subsisted on the modified assault rations for periods of from 2 to 5 days in the month of May at the time when the high camps were being established and during the assault phase.

The party was much fitter physically at all stages of the expedition than on the Cho Oyu expedition the previous year, for which objective evidence is provided by the records of body-weight. The average loss of weight during the first 26 days after arrival at Tyangboche (13,000 ft.) was only $2 \mathrm{lb}$. (range from -8 to +3 lb.) compared with i $\mathrm{lb}$. (range from -6 to $-\mathrm{r} 4 \mathrm{lb}$.) during the corresponding period on Cho Oyu. This was the so-called acclimatization phase during which the climbers were living at altitudes ranging from $\mathrm{I} 3,000$ to $\mathrm{x} 8,000 \mathrm{ft}$. and making ascents to $20,000 \mathrm{ft}$. During the 2 nd month, spent mainly in the Western Cwm $(20,500$ to $2 \mathrm{I}, 000 \mathrm{ft}$.), with short periods at altitudes up to $24,000 \mathrm{ft}$. and in some instances ascents to $26,000 \mathrm{ft}$., the average loss of weight was $4 \mathrm{lb}$. (range from $-\mathrm{II}$ to $+3 \mathrm{lb}$.).

Evaluation of the calorie value and composition of the food eaten at various stages of the expedition (Table 4 ) shows that the calorie intake during the approach march was comparable with that in 1952 , but the intake of fats was twice as high in 1953 as in $195^{2}$, indicating a less bulky diet. The calorie intake at Base Camp and in the Western Cwm was higher than the calorie intake during the high altitude phase of the Cho Oyu expedition. There was, however, a good deal of variation between individuals, which the available records do not reveal. For example, at any given camp the same amount of food would be served to each climber at supper, but not every one would eat all of it, and no record was made of the waste. Few quantitative records are available of the food eaten on the Lhotse Face and above it, that is to say at altitudes above $22,000 \mathrm{ft}$. In Table 4 values are given for the composition of the modified assault ration, of which some climbers stated that 
Table 4. Analysis of the food eaten at the various stages of the Everest expedition, 1953

\begin{tabular}{|c|c|c|c|c|}
\hline \multirow[b]{2}{*}{$\begin{array}{l}\text { Activity and } \\
\text { altitude (ft.) }\end{array}$} & \multicolumn{4}{|c|}{ Composition of ration } \\
\hline & $\begin{array}{l}\text { Protein } \\
\text { (g) }\end{array}$ & $\begin{array}{l}\text { Fat } \\
\text { (g) }\end{array}$ & $\begin{array}{l}\text { Carbohydrate } \\
(\mathrm{g})\end{array}$ & $\begin{array}{l}\text { Calories } \\
\text { (Cal.) }\end{array}$ \\
\hline Approach march* & 110 & $23 I$ & 453 & 4328 \\
\hline Base Camp i 8,000* & $8 \mathrm{r}$ & 190 & 437 & 3786 \\
\hline $\begin{array}{l}\text { Camps } 3 \text { and } 4 \\
20,500-21,200 \dagger\end{array}$ & 75 & I 84 & 478 & 3869 \\
\hline Assault $f$ & 46 & 54 & 638 & 3208 \\
\hline
\end{tabular}

most was eaten. There was general agreement that all or nearly all the sugar was consumed, and it alone would yield up to I $500 \mathrm{Cal}$. Ward kept a record of the food eaten by him and Noyce over $48 \mathrm{~h}$ in going from Camp $4(2 \mathrm{I}, 200 \mathrm{ft}$.) to Camp 7 $(24,000 \mathrm{ft}$.) Evaluation of his record shows an intake of $2600 \mathrm{Cal} . / \mathrm{man} /$ day. Hillary described how he and Tensing spent much of the night in camp at $27,900 \mathrm{ft}$. in brewing tea. They added three or four heaped dessertspoons of sugar to each mug of tea in addition to milk. For food they ate sardines and Vitawheat biscuits. On getting back to Camp 4 the day after the ascent to the summit, Hillary ate two omelettes and $6 \mathrm{oz}$. of salmon at a sitting, and drank 2 pt. of lemonade.

At all stages of the 1953 expedition the food intake was much greater than that recorded by Shipton (1938) on the 1935 expedition to Mount Everest. Shipton stated that food intake did not exceed 2000 Cal. between I7,000 and 21,000 ft., and $1500 \mathrm{Cal}$. at higher altitudes.

The question of fluid intake at high altitudes where all water has to be obtained by melting snow was given special consideration in planning the r 953 expedition, since there was evidence on certain previous expeditions that the climbers had become seriously dehydrated. The Swiss, for example, in their spring expedition to Everest in 1952, had less than I pt./man/day during 3 days spent on the South Col $\left(25,85^{\circ} \mathrm{ft}\right.$. $)$, and it was considered that fluid deficiency contributed to the extreme state of exhaustion which they suffered. Measurement of water intake on Cho Oyu showed a daily intake of from 5 to $7 \mathrm{pt}$. in beverages and soup, and the observation was confirmed on Everest in 1953. Probably at no time during the 1953 expedition did fluid intake fall below requirements for more than a day at a time. The climbers passed urine two or three times a day up to $22,000 \mathrm{ft}$. The recorded urine output in one subject up to that altitude was from $I \cdot 2$ to $I \cdot 51$. a day. During the assault phase most climbers could remember having passed water twice a day, which should be compared with a statement of Finch (personal communication) that he was the only member of a party of five to pass water over a period of $17 \mathrm{~h}$ spent above 25,000 feet.

A further question which requires to be raised is that of vitamin requirements, which might be inadequate in a party subsisting for 3 months on packed rations. 
In the I953 expedition, as on Cho Oyu the previous year, each climber was issued with a supply of compound vitamin tablets containing ascorbic acid $75 \mathrm{mg}$, vitamin A 5000 i.u., vitamin D 500 i.u., thiamine $3.0 \mathrm{mg}$, riboflavin $2.0 \mathrm{mg}$, nicotinamide $20.0 \mathrm{mg}$, folic acid $1.0 \mathrm{mg}$, vitamin $B_{12} \times \mu \mathrm{g}$. Apart from ascorbic acid, however, the intake of which was about $14 \mathrm{mg}$ a day, the diet at all phases of the $1953 \mathrm{ex}$ pedition except the assault was adequate in vitamin content without further supplements.

\section{Discussion}

The evidence which has just been presented suggests that the general efficiency of Himalayan expeditions can be improved by providing a diet of greater variety and palatability and more consistent with European food habits than has been customary on many previous expeditions, in particular small expeditions with limited funds. Members of an expedition starting out on an unaccustomed and excessively bulky diet nearly resembling the local native diet are likely to suffer considerable loss of weight and digestive disturbance during the first 2 months, but experience has shown that in most instances adaptation will eventually occur.* The ability of experienced Himalayan travellers to adapt themselves to native diet appears to be greater than that of newcomers on their first expedition. On expeditions to a high and difficult mountain the extra expense of taking composite rations is fully justified if it increases the general efficiency of the party and prevents even a single casualty.

It has been the writer's experience that men in a state of great fatigue prefer to eat nothing rather than put up with food for which they have no taste, nor are they able to eat if their water requirements are unmet. Insufficient intake of food, especially in combination with fluid deficiency, leads to deterioration in performance if continued for more than $I$ or 2 days.

At altitudes above 22,000 ft., where deterioration from the effect of anoxia is inevitable, it is obviously important to avoid accelerating the process by allowing food and fluid deficiencies to arise. Indeed, apart from mountaineering considerations, it is not surprising to find that expeditions that have failed to provide themselves with adequate arrangements to meet their food and water requirements at high altitude have failed in their objective.

The demand for sugar by climbers at high altitude has long been recognized, but the requirement is so large that the supply has seldom been sufficient. Even men who at sea level are not fond of sugar and sweets find that their sugar intake increases as they go higher. Sugar seems to taste less sweet at high altitudes, and large quantities are needed to sweeten beverages. The increased appetite for sugar at high altitude has a physiological justification in terms of respiration. The oxygen intake corresponding to a given work output is less on a high than on a low R.Q. Houston (1947) has pointed out that at $20,000 \mathrm{ft}$. the effect on the mean capillary oxygen pressure of a rise in R.Q. from 0.8 on a mixed diet to $\mathrm{I} \cdot \mathrm{O}$ on pure carbohydrate would be equivalent to a reduction in altitude of $2000 \mathrm{ft}$.

* Chronic diarrhoea, probably of infective origin but kept going by unsuitable food, is not uncommon, and, on Cho Oyu in 1952, a case of sprue occurred. 
Loss of weight is a characteristic effect of high altitude and has been observed on physiological as well as mountaineering expeditions to high altitude (Barcroft, I925; Dill, I938; Hingston, I925; Warren, I937; Bauer, I931). Loss of weight is associated with anorexia, which is one of the most characteristic symptoms of altitude intolerance. It has often been observed, however, that the general health and performance of a party may be good in spite of loss of weight, and it has been inferred that some reduction in body-weight may be an advantage since it reduces the work of climbing. After the Cho Oyu expedition in 1952, we were inclined to interpret some degree of weight loss as part of the acclimatization process. It was of great interest, therefore, to find that on Everest body-weight was so much better maintained by more careful acclimatization and improvement of the diet.

\section{SUMMARY}

I. The dietaries of a typical postwar Himalayan expedition and of the I953 Everest expedition are described.

2. Himalayan expeditions usually live off the country, supplementing local food from bulk stores. The I 953 party had composite rations, thus providing a more variable and palatable diet than is possible for a party living mainly off the country. The sudden change to a strange and bulky diet at the beginning of the expedition was avoided by using composite rations.

3. Climbers living at altitudes above $19,000 \mathrm{ft}$. usually consume about i2 oz. sugar a day and a large proportion of their food takes the form of sugar dissolved in beverages. They develop strange food cravings and prefer to do without rather than eat food that is unpalatable to them.

4. The Everest party in 1953 ate normal food up to $21,000 \mathrm{ft}$. This was explained by better acclimatization, the greater palatability of the composite ration and the use of pressure cookers.

5. The general physical condition of the members of the 1953 expedition was considered to be better than on the 1952 expedition, and the loss of body-weight which is characteristic of sojourn at high altitude was less than on previous expeditions.

Grateful thanks are due to Miss M. W. Grant, of the Human Nutrition Research Unit, London School of Hygiene, for her help with the dietary analyses.

\section{REFERENCES}

Barcroft, J. (1925). The Respiratory Function of the Blood. Part 1, p. 190. Cambridge: University Press. Bauer, P. (193 I). Im Kampf um den Himalaya, p. 146. Munich: Knorr \& Hirth.

Dill, J. B. (1938). Heat, Life and Altitude, p. I44. Cambridge, Mass.: Harvard University Press. Hingston, R. W. G. (1925). Geogr. F. 65, 4 . 
Houston, C. S. (1947). F. Aviat. Med. 18, 237.

Hunt, J. (1953). The Ascent of Everest. Appendix 6. Diet, by L. G. C. Pugh \& G. C. Band. London: Hodder \& Stoughton.

Shipton, E. (1938). Chem. \& Ind. 57, $123 \mathrm{r}$.

Warren, G. B. (1937). Geogr. F. 90, 127.

\section{The Evolution of Polar Rations}

By G. C. L. Bertram, Scott Polar Research Institute, Cambridge

Much thought, effort and ingenuity have gone into the development of polar rations in the course of the last 50 years, and indeed for a century earlier. Insufficient knowledge of nutritional principles, lack of perspective and, more especially, lack of controlled experiment, have all had their successive influence on the evolution of polar rations. The lack of sufficient experiment, still largely applies to-day, though, it may be said at once, that some of the need for specially superior rations has disappeared with the advent of vehicles that can travel over the snow.

Throughout the course of the deliberate development of polar rations certain assumptions and criteria have had special weight. The availability of ample water has always been assumed. Lightness of weight has been of extreme importance. High calorie content has been urgently sought as, in recent times, has nutritional completeness in terms of several months, and a suitable ratio of protein, carbohydrate and fat. Further features are simplicity in preparation, sufficient palatability, and permanence of quality in store. Subsidiary have been such aspects as retention of quality during passage through the tropics, packaging against the teeth of dogs and the effects of extraneous water, and the limitation of expense. In fulfilment of these requirements, it is worthy of note that some of the very earliest canned foods to be made were used in polar travel. Particular mention may be made of the preserved meats, soups and vegetables which formed part of the stores taken by Sir Edward Parry on his Arctic expeditions between 1819 and 1825 .

It seems a fair assertion that, in the evolution of polar rations, the factor of palatability has played no great part. The healthy and willing organism, working at low altitudes, when hungry and having no choice of diet, is well content with what is available. Lack of palatability has rarely obtruded itself except when there has been a choice. Indeed it may even be suggested that maintenance of a polar expedition on a humble but adequate diet will lead to greater contentment than its provisioning with a large assortment so that choice must be exercised. With the more educated type of man I believe that raising the standard of living in polar conditions more often than not leads to less satisfaction.

It must be stressed again that here the concern is solely with rations for the use of expeditions, that is to say food for willing and intelligent volunteers ready to accept a severe personal discipline. It is not a question of military rations for use in 